\title{
Apis mellifera ruttneri, a new honey bee subspecies from Malta
}

\author{
WS Sheppard ${ }^{\text {I* }}$ MC Arias ${ }^{2}, \mathrm{~A} \mathrm{Grech}^{3}$, MD Meixner ${ }^{1,4}$ \\ 'Department of Entomology, 166 FSHN Building, Washington State University, \\ Pullman, WA 99164-6382, USA; \\ ${ }^{2}$ Department of Biology, University of São Paulo, São Paulo, SP, Brasil; \\ ${ }^{3}$ Xehda Ghasel, Triq il-Ferrovija, Attard, BZN 02, Malta; \\ ${ }^{4}$ Institut für Bienenkunde, 2 Karl von Frisch Weg, 61440 Oberursel, Germany
}

(Received 17 July 1997; accepted 6 August 1997)

\begin{abstract}
Summary - Endemic honey bees of the island nation of Malta are described as a distinct geographic race, Apis mellifera ruttneri, based on discriminant morphological analysis. Mitochondrial DNA and behavioral characteristics support a closer relationship of $A$ m ruttneri to $A$ m intermissa of North Africa than to European subspecies, similar to the situation with endemic island honey bees of Sicily ( $A$ m sicula). These findings suggest a shared evolutionary history among bees populating the islands of the central Mediterranean region. Recent importations of non-native honey bee subspecies present a clear threat to conservation of this unique honey bee of limited distribution. The subspecies is named after Professor Friedrich Ruttner, who has contributed so much to the understanding of intra-specific taxonomy in the honey bee.
\end{abstract}

Apis mellifera ruttneri / taxonomy / subspecies / Malta / evolution

\section{INTRODUCTION}

Within the endemic range of the honey bee, Apis mellifera L, behavioral and morphological variation provides the basis for subspecific classification. Phylogenetic relationships based on this classification have been used to form hypotheses about the ori- gins and subsequent dispersion of particular races or groups (Ruttner, 1988). In some cases, alternative hypotheses have been proposed based on molecular data (Cornuet and Garnery, 1991; Garnery et al, 1992). However, one interesting commonality has been the consistency with which molecular and morphological data support a phylogeo-

\footnotetext{
* Correspondence and reprints
}

Tel: (1) 509335 5180; fax: (1) 509335 1009; e-mail: shepp@mail.wsu.edu 
graphic association of honey bee subspecies from Mediterranean island sources to a subspecies of northern Africa, A m intermissa, or perhaps to Iberian honey bees with African origins (Badino et al, 1985; Garnery et al, 1993; Arias and Sheppard, 1996).

Morphometric studies demonstrate clear distinctiveness of several island subspecies, including $A m$ sicula of Sicily and $A m$ adami of Crete, and suggest that isolation and reduced gene flow was followed by insular adaptation and differentiation. Further, fossil evidence supports a shared evolutionary history for the mammalian fauna of Sicily and Malta, predating the Pleistocene. On the basis of these factors, we investigated the honey bees of Malta compared to their closest neighboring subspecies of Africa, Sicily and Italy.

\section{MATERIAL AND METHODS}

Samples of adult honey bees were collected from 15 colonies in eight apiaries throughout Malta and preserved in liquid nitrogen. A subset of each sample was transferred to $70 \%$ ethanol for morphometric analysis. Fifteen worker bees per sample were dissected and measured for 39 morphometric characters according to Ruttner et al (1978). Wing venation angles and characters of size (except length of the tergites) were measured with a CCD camera and an on-screen measuring system (Meixner, 1994). Length of tergites and characters of pigmentation and pilosity were measured with a microscope and an ocular micrometer. The statistical analysis of the data was performed with SPSS/PC (1988), using the programs for cluster analysis and discriminant analysis. All characters measured were included in the analyses. Reference colony samples of $A m$ carnica (31), ligustica (25), adami (24), intermissa (11) and sicula (17) from the collection of the Institut für Bienenkunde, Oberursel, were included in the statistical analyses.

Characterization of mitochondrial DNA in the Maltese samples was based on the fragment profile produced by $E c o \mathrm{R} I$ restriction enzyme digestion. Extraction and non-Southern blot visualization methods were published previously (Sheppard and McPheron, 1990; Schiff et al,
1994). Voucher specimens of $A$ m ruttneri were deposited at the MT James Museum, Washington State University and the Institut für Bienenkunde, Oberursel.

\section{RESULTS}

A cluster analysis of the morphological data, including the Malta bees and all the reference samples, identified six different groups that could be confirmed by discriminant analysis. In figure 1, discriminant factor 1 (accounting for $45 \%$ of the variation) is plotted against factor $2(30 \%)$. The bees of Crete, and those of Italian/Carniolan origin are clearly very distinct from the bees of North Africa, Sicily and Malta, which cluster closer together. While this figure shows strong relations of the Maltese bees to the $A$ $m$ sicula / A m intermissa group, it does not provide much resolution among these races. However, 'contamination' of the Malta samples with bees imported from Italy can be ruled out by these results.

A discriminant analysis including only the Maltese honey bees, $A$ $m$ sicula, $A m$ intermissa and $A$ m ligustica provides better resolution of this cluster (fig 2). Samples of A $m$ ligustica were included in this analysis to further confirm that the samples collected in Malta are distinct from this group. Here, too, factor 1 (67\% of the variance) is plotted against factor $2(27 \%)$.

Figure 3 shows a detailed analysis of $A \mathrm{~m}$ intermissa, $A$ m sicula and the honey bees from Malta. Factor 1 ( $78 \%$ of the variance) is plotted against factor $2(22 \%)$. The characters contributing most to the discrimination of these races are 'dark stripe on tergum 4', length of forewing, width of wax mirrors, length and width of metatarsus and three characters of wing venation. Analysis of mtDNA with EcoR 1 restriction enzyme revealed that the haplotypes of Maltese bees were typical of those found in both $A m$ sicula and A m intermissa (Smith et al, 1991; WSS, unpublished data). 


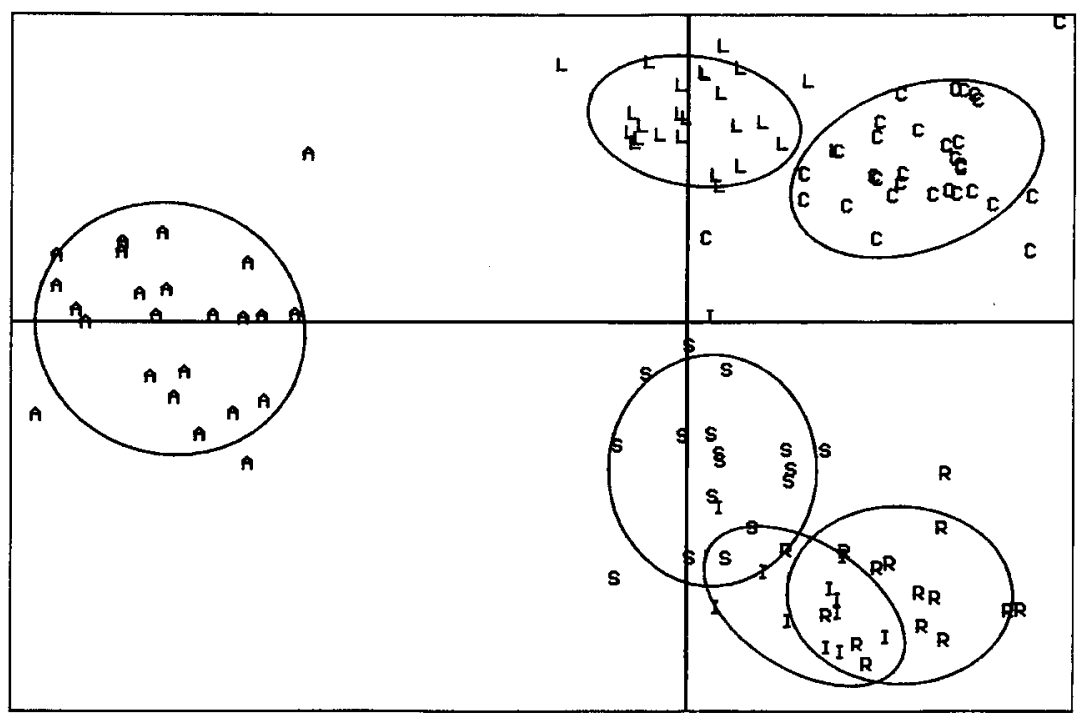

Fig 1. Discriminant analysis including $A$ m adami $(\mathrm{A})$, A $m$ carnica $(\mathrm{C})$, A $m$ ligustica $(\mathrm{L})$, A $m$ intermissa (I), A m sicula (S) and A m ruttneri (R). Letters represent individual colony samples. Abscissa: discriminant factor 1, ordinate: discriminant factor 2 . The ellipses of confidence $(75 \%)$ are given.

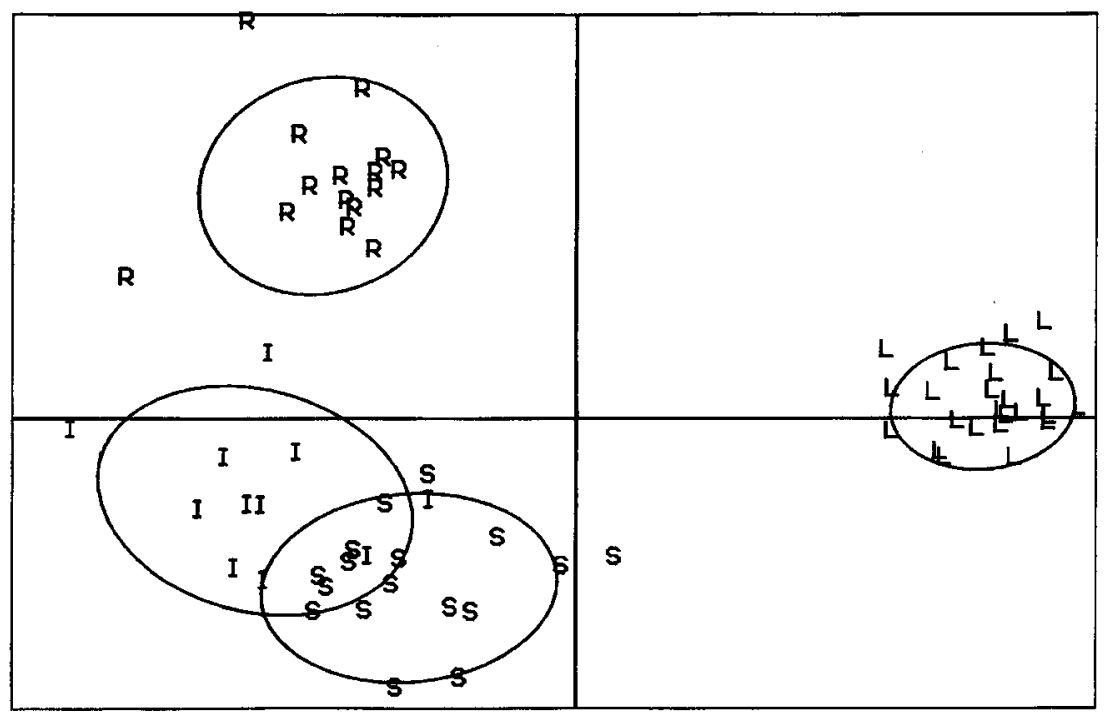

Fig 2. Positions of A m ligustica (L), A m intermissa (I), A $m$ sicula (S) and $A$ m ruttneri $(\mathrm{R})$ in a discriminant analysis. Abscissa: discriminant factor 1, ordinate: discriminant factor 2 . The ellipses of confidence $(75 \%)$ are given. 


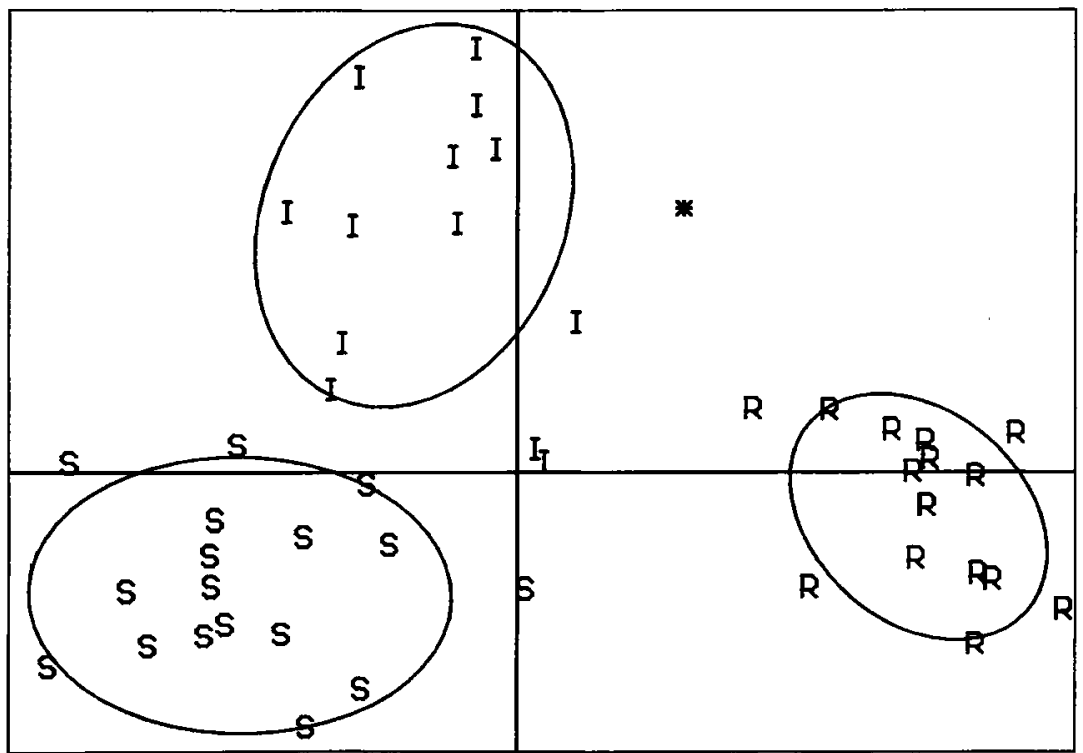

Fig 3. Discriminant analysis including only the 'African' group of subspecies $A$ m intermissa (I), $A$ $m$ sicula $(\mathrm{S})$ and $A$ m ruttneri (R). Abscissa: discriminant factor 1, ordinate: discriminant factor 2 . A single sample collected in Malta by $\mathrm{Br}$ Adam in the 1950s is denoted by an asterisk.

\section{Description of Maltese bees}

The honey bees of Malta are similar in size to $A$ m sicula and $A$ m intermissa, but have shorter legs and wings; the wings are also much narrower. The abdomen of the bees found in Malta is considerably wider (sternum index $[\mathrm{SI}]=77.74$ ) than in its relative, A $m$ intermissa (81.52). Thus, A m ruttneri is the 'broadest' subspecies of $A$ mellifera, even broader than $A$ m mellifera $(\mathrm{SI}=78.61)$ (Ruttner 1992). While the pigmentation of the bees does not differ much from $A m$ intermissa or A $m$ sicula, they have considerably longer hair on the abdomen. Whereas the cubital distances of $A m$ ruttneri differ greatly from $A m$ sicula and $A m$ intermissa, the cubital index is similar to $A$ m sicula, but different from $A$ m intermissa. Table I shows the means and standard deviations for some characters for $A$ m ligustica, $A \mathrm{~m}$ sicula, A m intermissa and the Maltese samples.

\section{DISCUSSION}

Morphometric analysis of the honey bees of Malta supports their classification as a distinct subspecies. They are clearly differentiated from the closest neighboring subspecies $A m$ intermissa, $A m$ sicula and $A m$ ligustica. We propose to name the subspecies Apis mellifera ruttneri in honor of Professor Friedrich Ruttner, who has contributed so much to the science of honey bee taxonomy.

The mitochondrial haplotype found in Maltese honey bees is typical of African and Sicilian subspecies. Previous studies demonstrated a phylogenetic link between $A$ $m$ sicula and African honey bees (Badino 
Table 1. Comparative characteristics of A m ligustica, A $m$ sicula, A m intermissa and A m ruttneri.

\begin{tabular}{lrrrr}
\hline Character & A m ligustica & A m sicula & A m intermissa & A m ruttneri \\
& $\mathrm{N}=25$ & $\mathrm{~N}=17, * 13$ & $\mathrm{~N}=1 I$ & $\mathrm{~N}=15, * 5$ \\
\hline Length of hair on tergum 5 & $28.23 \pm 1.46$ & $31.38 \pm 2.94$ & $31.95 \pm 4.91$ & $34.91 \pm 3.67$ \\
Width of tomentum & $97.84 \pm 7.88$ & $88.45 \pm 3.09$ & $79.67 \pm 9.79$ & $86.60 \pm 3.43$ \\
Length proboscis & $640.10 \pm 7.38$ & $635.17 * \pm 6.48$ & $631.13 \pm 10.4$ & $629.64 * \pm 7.84$ \\
Pigmentation tergum 2 & $7.93 \pm 0.44$ & $1.78 \pm 0.74$ & $1.56 \pm 0.48$ & $1.19 \pm 0.34$ \\
Pigmentation tergum 3 & $6.96 \pm 0.63$ & $2.95 \pm 0.72$ & $3.24 \pm 0.59$ & $3.65 \pm 0.66$ \\
Pigmentation tergum 4 & $4.19 \pm 0.58$ & $1.36 \pm 0.72$ & $1.49 \pm 0.72$ & $0.36 \pm 0.39$ \\
Length forewing & $915.39 \pm 9.18$ & $900.28 \pm 9.09$ & $903.02 \pm 15.03$ & $869.66 \pm 11.39$ \\
Width forewing & $319.77 \pm 4.38$ & $306.08 \pm 4.34$ & $303.53 \pm 6.22$ & $293.84 \pm 4.26$ \\
Wing venation angle G18 & $93.22 \pm 1.58$ & $98.09 \pm 2.35$ & $101.58 \pm 2.49$ & $97.97 \pm 2.88$ \\
Total length of leg & $793.32 \pm 7.57$ & $804.17 \pm 9.66$ & $799.56 \pm 13.29$ & $775.83 \pm 9.76$ \\
Body size (tergum 3+ & $438.61 \pm 5.86$ & $441.04 \pm 6.15$ & $450.25 \pm 15.66$ & $446.78 \pm 5.76$ \\
tergum 4) & & & & \\
Sternum 6 index (slenderness) & $83.91 \pm 1.64$ & $83.18 \pm 1.74$ & $81.52 \pm 2.62$ & $77.74 \pm 1.51$ \\
Cubital index & $2.54 \pm 0.15$ & $2.42 \pm 0.24$ & $2.25 \pm 0.10$ & $2.41 \pm 0.24$ \\
\hline
\end{tabular}

Values are means and standard deviations of samples, each sample representing one colony. $N=$ number of sampled colonies, with asterisks for sample numbers for proboscis. Measurements of size are in units of 1:100 mm, wing venation angles are in degrees. Characters of pigmentation: $0=$ completely dark, $9=$ completely bright (yellow). Measurements taken according to Ruttner (1988).

et al, 1985; Garnery et al, 1993). The shared mitochondrial heritage between $A$ m sicula and $A$ m ruttneri probably reflects common elements in the origins of these subspecies from the African lineage. The present day occurrence of honey bee populations with African mtDNA lineages in Iberia (Smith et al, 1991) and the Mediterranean islands must also be interpreted in light of extensive refugia formation and bottlenecks that occurred repeatedly during the eight glacial-interglacial cycles known to have occurred in Europe during the past 800000 years (Kukla, 1977).

Fossil remains of mammals of African origin, such as hippopotamus and elephant, are known from Pleistocene formations in both Sicily and Malta (Potts and Behrensmeyer, 1992; Zammit-Maempel, 1985). Extensive adaptations for insular conditions in these animals, such as an overall reduction in size to 'pygmy' status, suggest that their occupation of Sicily and Malta was of con- siderable duration, predating the Pleistocene. Whether the movement of honey bees of the 'African' branch to Iberia and the Mediterranean islands reflects dispersal processes similar to those of African mammals remains unanswered. Preliminary evidence drawn from mitochondrial DNA supports a recent (Pleistocene) origin for honey bee subspecies (Cornuet and Garnery, 1991; Arias and Sheppard, 1996), as hypothesized by Ruttner (1988). Resolution of the issue should be improved through calibration of the rates of sequence divergence from additional molecules.

Behaviorally, A m ruttneri appears welladapted for the seasonally xeric conditions of Malta. They are able to find food and water during the dry period from April through September and normally rear brood throughout the year (AG, unpublished data). Other characteristics of $A m$ ruttneri support the close association with $A$ m intermissa and $A$ m sicula, including the pro- 
duction of large numbers of queen cells prior to swarming (up to 80). Maltese bees also show an ability to defend against local predacious wasps, a behavior reported for A $m$ sicula (Ruttner, 1992). This behavior is not found in Italian stocks imported to Malta (AG, unpublished data). Maltese bees exhibit increased defensiveness during periods of low humidity and absconding behavior during prolonged dearth periods.

Although the origin of $A$ mellifera is likely to be further east, Ruttner (1988) considers the Mediterranean region to be the center of diversity for the species based on the large number of subspecies in the circum-Mediterranean region. The distinct insular honey bees of Sicily, Crete, Cyprus and Malta appear to support this contention. Unfortunately, the potential for loss of this germplasm is high, given the limited geographic ranges of these subspecies, the loss of feral populations to introduced parasitic mites, and the importation of non-native stocks. Further analysis of variation in the honey bee using molecular genetic approaches is crucial to establish the extent of the species diversity and to identify endemic populations that most critically require attention for conservation.

\section{ACKNOWLEDGMENTS}

We are indebted to numerous beekeepers of Malta for allowing us to sample their colonies. Agnes Mohr assisted in morphometric analysis. We thank the Ministry of Food, Agriculture and Fisheries of Malta for providing logistical support for collecting activities.

\section{Résumé - Apis mellifera ruttneri, une nouvelle race d'abeille mellifère à Malte.} Les abeilles endémiques de l'île de Malte sont décrites comme une race géographique distincte, $A$ m ruttneri, sur la base d'une analyse morphologique discriminante. Les abeilles de Malte sont semblables en taille à
$A m$ sicula et à $A m$ intermissa, mais possèdent des pattes et des ailes plus courtes ; les ailes sont également beaucoup plus étroites. L'abdomen des abeilles trouvées à Malte est beaucoup plus large (index du sternum $(\mathrm{SI})=77,74)$ que celui de la race apparentée $A$ m intermissa $(\mathrm{SI}=81,52)$. Ainsi $A m$ ruttneri est la sous-espèce d'A mellifera la plus large ; elle est même plus large que $A$ m mellifera $(\mathrm{SI}=78,61)$ (Ruttner, 1992). Le tableau I donne les moyennes et les déviations standard de certains caractères pour $A m$ ligustica, A $m$ sicula, A $m$ intermissa et pour les échantillons maltais. L'haplotype mitochondrial trouvé chez l'abeille maltaise est typique des sous-espèces africaine et sicilienne. Les caractéristiques de l'ADN et celles du comportement plaident en faveur d'une relation plus étroite d'A $m$ ruttneri avec $A$ m intermissa d'Afrique du Nord qu'avec les sousespèces européennes, situation semblable à celle des abeilles endémiques de Sicile $(A m$ sicula). Ces résultats suggèrent que les abeilles qui ont peuplé les îles de la Méditerranée centrale ont connu un développement commun au cours de l'évolution. La sous-espèce est nommée ruttneri en hommage au professeur F Ruttner qui a tant contribué à la connaissance de la taxinomie infraspécifique de l'abeille mellifère. Malheureusement, en raison de l'étendue restreinte de la race, de la perte causée aux populations locales par l'acarien Varroa jacobsoni et de l'importation de souches de races étrangères, la situation de cette race est en grand danger. La probabilité de la voir disparaitre est très élevée.

\section{Apis mellifera ruttneri / taxonomie / race / Malte / évolution}

\section{Zusammenfassung - Apis mellifera rutt-} neri, eine neue Honigbienenrasse von Malta. Endemische Honigbienen der Insel Malta werden auf Grund der morphologischen Diskriminanzanalyse als eine eigene 
geographische Rasse, $A$ m ruttneri, beschrieben. Ihre Größe ist der der $A$ m sicula und $A$ $m$ intermissa ähnlich, sie haben aber kürzere Beine und Flügel; außerdem sind die Flügel viel schmaler. Der Hinterleib der Bienen aus Malta ist deutlich breiter (Sternum Index $(\mathrm{SI})=77,74)$ als bei der verwandten Unterart $A$ m intermissa (SI $=81,52)$. $A m$ ruttneri ist demnach die breiteste Rasse von A mellifera, sogar noch breiter als $A$ m mellifera $(\mathrm{SI}=78,61$ ) (Ruttner 1992). Tabelle I zeigt die Mittelwerte und Standardabweichungen einiger Merkmale von $A m$ ligustica, A $m$ sicula, A m intermissa und den maltesischen Proben. Der Haplotyp der Mitochondrien der Malta-Bienen ist typisch für die afrikanischen und sizilianischen Rassen. DNA und Verhaltensmerkmale sprechen für eine engere Verwandtschaft von A $m$ ruttneri zur nordafrikanischen $A m$ intermissa als zu europäischen Rassen, ähnlich wie bei der ebenfalls endemischen sizilianischen Honigbiene ( $A m$ sicula). Diese Ergebnisse lassen auf eine gemeinsame Entwicklung der Bienen der zentralen Inseln des Mittelmeers im Verlauf der Evolution schließen. Diese Rasse ist nach Friedrich Ruttner benannt, der so viel zum Verständnis der intraspezifischen Taxonomie der Honigbienen beigetragen hat. Durch die begrenzte geographische Verbreitung dieser Rasse, durch die Verluste der Wildpopulation durch die eingeführte parasitische Milbe und durch die Importation von Zuchtstämmen fremder Bienenrassen muß der Bestand dieser einzigartigen Bienenpopulation leider als sehr gefährdet gelten. Die Wahrscheinlichkeit des vollständigen Verlustes ist sehr hoch.

\section{Apis mellifera ruttneri / Taxonomie / Geo- graphische Rasse / Malta / Evolution}

\section{REFERENCES}

Arias MC, Sheppard WS (1996) Molecular phylogenetics of honey bee subspecies (Apis mellifera L.) inferred from mitochondrial DNA sequences. $\mathrm{Mol}$ Phylogenet Evol 5, 557-566.

Badino G, Celebrano G, Manino A, Longo S (1985). Enzyme polymorphism in the Sicilian honeybee. Experientia 41, 752-754

Cornuet JM, Garnery L (1991) Mitochondrial DNA variability in honeybees and its phylogenetic implications. Apidologie 22, 627-642

Garnery L, Cornuet JM, Solignac M (1992) Evolutionary history of the honey bee Apis mellifera inferred from mitochondrial DNA analysis. $\mathrm{Mol}$ Ecol 1, 145-154

Garnery L, Solignac M, Celebrano G, Cornuet J-M (1993) A simple test using restricted PCR-amplified mitochondrial DNA to study the genetic structure of Apis mellifera L. Experientia 49, 1016-1021

Kukla GJ (1977) Pleistocene land-sea correlations 1. Europe. Earth-Sci Rev 13, 307-374

Meixner M (1994) Analyse polymorpher Subspezies von Apis mellifera L. Morphometrische und molekulare Untersuchungen an den europäischen Rassen Apis mellifera carnica und ligustica und den afrikanischen Rassen Apis mellifera monticola und scutellata. PhD Thesis, Johann-WolfgangGoethe-University, Frankfurt

Potts R, Behrensmeyer AK (1992) Late cenozoic terrestrial ecosystems. In: Terrestrial Ecosystems through Time: Evolutionary Paleoecology of Terrestrial Plants and Animals (AK Behrensmeyer, JD Damuth, WA DiMichele, R Potts, HD Sues, SL Wing, eds), Univ Chicago Press, Chicago, 419-514

Ruttner F, Tassencourt L, Louveaux J (1978) Biometrical-statistical analysis of the geographical variability of Apis mellifera L. Apidologie 9, 363-381

Ruttner F (1988) Biogeography and Taxonomy of Honeybees. Springer Verlag. Berlin

Ruttner F (1992) Naturgeschichte der Honigbienen. Ehrenwirth Verlag, Munich

Schiff NM, Sheppard WS, Loper GM, Shimanuki H (1994) Genetic diversity of feral honey bee (Hymenoptera: Apidae) populations in the Southern United States. Ann Entomol Soc Am 87, 842-848

Sheppard WS, McPheron BA (1990) Ribosomal diversity in Apidae. In: Diversity in the Genus Apis (DR Smith, ed), Westview, Oxford, 89-102

Smith DR, Palopoli MF, Taylor L, Garnery L, Cornuet J.M, Solignac M, Brown WM (1991) Geographical overlap of two mitochondrial genomes in Spanish honey bees (Apis mellifera iberica). $J$ Hered 82, 96-100

SPSS/PC+ (1988) V2 0, SPSS Inc, 444 North Michigan Ave, Chicago, IL

Zammit-Maempel G (1985) Biology and ecology of Ghar Dalam cave, Malta. Atti Soc Tosc Sci Nat, Mem, Serie A, 92, 351-374 